\title{
Teachers' and Students' Perceptions on The Use of SSI-based Assessment Instrument for Measuring Students' Ability to Collaborate
}

\author{
Apriyani Nurtika $^{1}$, Sunyono $^{2}$, Dewi Lengkana ${ }^{3}$ \\ \{apriyaninurtika76@gmail.com ${ }^{1}$, sunyono_ms@yahoo.com ${ }^{2}$, dewilengkana76@gmail.com ${ }^{3}$ \}
}

Science Education, Master Program, Lampung University, Indonesia ${ }^{1}$, Chemistry Education, Lampung University, Indonesia ${ }^{2}$, Biology Education, Lampung University, Indonesia ${ }^{3}$

\begin{abstract}
The purpose of this study was to analyze and explain teachers' and students' perceptions on the SSI-based assessment instrument for measuring students' ability to collaborate. The method used was the descriptive method. The samples of this study cover ten junior high school teachers and one hundred junior high school students from ten different schools. Data collection was administered by means of questionnaires, while the proportions technique was used for analyzing the collected data. The results show that teachers' perceptions on the SSI-based instrument assessment in the implementation aspect were in low category, because in the learning process the teachers did not raised the issue of science (SSI) often (medium category). Learners' perceptions of the aspect of collaboration ability were also in low category as teachers have not assessed learners' ability to collaborate. It can be concluded that the SSI-based assessment instrument is needed by both teachers and learners to accurately measure learners' ability to collaborate.
\end{abstract}

Keywords: assessment instrument, issue of science (SSI), collaborate skills.

\section{Introduction}

In the 21 st century, education plays a crucial role in improving the quality of human resources. The human resources required are not only those with high quality, but also those who are skilled. The skills required cover the ability to: collaborate, think in higher order, work creatively and skillfully, tolerate and adapt to various cultures, communicate well, and commit to life-long learning [1]. A set of special abilities learners need to have covers the ability to create and innovate, communicate and collaborate, research and gain information, think critically, solve problems, make decisions, involve in digital citizenship, comprehend concepts, and operate products of technology [2]-[4].

As mentioned earlier, ability to collaborate is one of the requirements learners need to have. Collaborating is all about learning to plan and work with partners, to consider different perspectives while actively contributing ideas in a discussion related to certain topic, as well as to listen and support others [5]. In order to create an effective collaboration in learning, five things have to be present: 1) positive inter-dependence; 2) individual responsibility; 3) growing interaction; 4) social awareness; 5) group management [6].

Collaboration in learning is regarded as important due to its was potential to improve critical thinking skills and to help learners achieve higher quality learning results [7],[8]. This is reflected through the results of the analysis on learners' achievement in science lessons in a study on the results of PISA (2015) in which there were 49 out of 72 participating countries had 
the average science score under 501 [9]. This shows that Indonesian learners' thinking performance is low. It also proves that most of them are in lower achiever category as they rely on memorization in dealing with science lessons. The test items in PISA demand the test takers to comprehend and solve problems. One of the possible causes of the poor test results was learners' lack of training and practice in dealing with such test items [10].

One of the many ways to measure learners' ability to collaborate is by conducting a lesson which demands learners to solve problems on topics closely related to their daily life matters that they are often unaware of. An example of this topic is the impact of global warming caused by the extreme raise of temperature. This problem is related to climate change and its impact on the ecosystem topic in science lessons. This problem is not only related to science, but also to social life that it is considered as a socio-scientific issue.

This indicates a need for improvement in the way science lesson is delivered in the classrooms in order to enable educators to measure learners' ability to collaborate while teaching them at the same time [11]. According to Khishfe, one of the many approaches often used for supporting learning is through the integration of socio-scientific issues into lessons [12]. SSI (socio-scientific issue) is regarded as an alternative to solve the afore mentioned issue because it involves the hot issues related to science which are growing in the society. The issues in SSI are science-related and open-ended, both conceptually and procedurally. These issues also have possible rational solving which could be influenced by several social aspects like cultural identity, politics, economy, and ethics [4].

The learning process aiming for fostering collaboration will only run effectively when teachers have good and continuous quality assurance [13],[14]. This can only be achieved through an assessment method which can provide a range of meaningful feedback when learning takes place. Therefore, the assessment process has to be integrated and authentic that will be able to measure learners' real ability [13].

Assessment on students has to meet the scoring standard covering competence of behavior, knowledge, and skills [15]-[17]. According to Poerwanti, assessment can be defined as a process to gain information in any forms which can be used as the base in making decision related to students' overall ability, receptive ability, curriculum, learning program, school condition, and policies, that it stands as a process which is able to determine the standard of measurement in teaching and learning [9].

In attempt to create a type of student with ability collaborate, a correct instrument for assessment and learning is required. SSI-based learning is assumed to possess that quality. Some studies have shown that SSI-based learning can enhance learners' scientific literacy and ability to collaborate [18]. Considering that, this study aims to describe teachers' and students' perceptions on the use of SSI-based assessment instrument for measuring students' ability to collaborate.

\section{Material and Method}

This research was conducted in August 2019 in ten junior high schools with the total samples of 10 teachers and 100 students. The descriptive approach was taken along with survey method to describe any phenomena happening in the field related to the use of SSI-based assessment instruments in measuring students' ability to collaborate. The data in form descriptive statistics were obtained through questionnaire. The data were analysed through manual scoring with every checked item considered as teachers' agreement with the statement 
in the questionnaire. The percentage of every questionnaire item was counted based on the formula proposed by Sudjana [19] and criteria proposed by Arikunto [20].

Table 1. Interpretation of Percentages in Questionnaire.

\begin{tabular}{cl}
\hline Percentage & \multicolumn{1}{c}{ Criteria } \\
\hline $80,1-100,0$ & Very High \\
$60,1-80,0$ & High \\
$40,1-60,0$ & Average \\
$20,1-40,0$ & Low \\
$0,0-20,0$ & Very Low \\
\hline
\end{tabular}

\section{Result}

The results of the data analysis in this research concludes that, in general, the SSI-based assessment instrument in learning activities has not been applied. It is shown on Table 2.

Table 2. Teachers' Perceptions on the use of SSI-based instrument for Measuring Learners' Ability to Collaborate.

\begin{tabular}{|c|c|c|c|}
\hline No & Question & $\begin{array}{l}\text { YES } \\
(\%)\end{array}$ & $\begin{array}{l}\text { NO } \\
(\%)\end{array}$ \\
\hline 1 & $\begin{array}{l}\text { Strategy/method implemented by teachers can help students in comprehending } \\
\text { materials in science lessons. }\end{array}$ & 50 & 50 \\
\hline 2 & Teacher understands forms of lessons based on social issues related to science. & 50 & 50 \\
\hline 3 & Teachers have ever implemented SSI-based lessons in teaching science. & 30 & 70 \\
\hline 4 & Teachers understand about ability to collaborate. & 40 & 60 \\
\hline 5 & Teachers have trained students to collaborate. & 40 & 60 \\
\hline 6 & It is important to measure students' ability to collaborate. & 80 & 20 \\
\hline 7 & Teachers have ever measured students' ability to collaborate. & 50 & 50 \\
\hline 8 & The results of measurement have met teachers' expectations. & 30 & 70 \\
\hline 9 & $\begin{array}{l}\text { An SSI-based assessment instrument is needed for measuring students' ability to } \\
\text { collaborate. }\end{array}$ & 100 & 0 \\
\hline \multicolumn{2}{|r|}{ Average } & 54 & 46 \\
\hline
\end{tabular}

On table 2, it is shown that the percentages of the affirmation and negation have significant difference for every item. Only very few teachers implemented SSI-based lessons in the 'average' category while the percentage of their use of assessment instrument for measuring learners' ability to collaborate remains in 'low' category.

Table 3. Students' Perceptions on the Use of SSI-base Assessment Instrument for Measuring Learners' Ability to Collaborate

\begin{tabular}{clcc}
\hline \multirow{2}{*}{ No } & \multicolumn{1}{c}{ Question } & $\begin{array}{c}\text { YES } \\
(\boldsymbol{\%})\end{array}$ & $\begin{array}{c}\text { NO } \\
(\boldsymbol{\%})\end{array}$ \\
\hline 1 & Learners find it difficult to understand materials in science lessons. & 85 & 15 \\
2 & Learners have experienced SSI-based learning in the classroom. & 25 & 75 \\
3 & Teachers relate learning materials with phenomena in the surrounding & 40 & 60 \\
& environment. & 50 & 50 \\
4 & Teachers bring materials containing science facts. & 50 & 50 \\
5 & Teachers deliver the materials only by lecturing. & 80 & 20 \\
6 & Teachers help learners in developing their ability to collaborate. & 21 & 79 \\
7 & Teachers ask learners to discuss some topics. & 0 & 100 \\
8 & Teachers often set time for learners to deal with some questions (time &
\end{tabular}


9 Teachers often rate learners' performance as the group discussion takes place 0 (seeking to solve problems through peer assistance).

10 Teachers set a number of sources of information to support problem solving 39 $0 \quad 100$ activity in discussions.

11 Teachers set turn (and pay attention) for each student in discussion. Average

4060

On Table 3, there is a clear difference between the percentages of affirmation and negation in every item. Most teachers have never measured learners' ability to collaborate (low percentage).

These findings are discussed further in the discussion section.

\section{Discussion}

\subsection{Teachers' perceptions on the use of SSI-based assessment instrument for measuring learners' ability to collaborate}

Based on the data analysis on Table 2, it can be seen that most teachers only rely on lecturing to help learners comprehend science lessons. This does not seem to attract learners as they consider science to be a difficult, abstract, and incomprehensible subject. Due to this, students' ability to collaborate remains unmeasured. This indicates a need for an attempt to improve the quality of activities during science lessons in the classroom in order to solve this persisting problem [21]. One of the many approaches to be taken is the socio-scientific issues (SSI). SSI is expected to be able to cover existing science-related problems or issues in the society [4].

Delivering lessons through SSI approach can also change the mood of the class from a teacher-centered into a more student-centered by means of discussions. Through discussions, collaboration can be fostered. In a discussion involving science-related issues, social interactions leading to the enrichment and perfection of students' understanding can be promoted [22]. This can be achieved by allowing students to explore issues based on concepts and scientific problems, contra version, and public discussion which are often influenced by socio-politics situation [23]. Bringing socio-scientific issues into lesson can drive students to become more accustomed to: applying science in their actions, developing their abilities to evaluate information they receive, making decisions on controversial socio-scientific problems, and getting into a discussion about socio-scientific issues burning in the society [24].

There are some other benefits of developing students' ability to collaborate, such as: tolerating differences in a group, improving their perceiving prowess, and enhancing problem solving and higher order thinking skill [25]. From Table 2, it can be inferred that only 50\% of the methods, which are mostly based on discussion and lectures, implemented by teachers could help learners in comprehending science lesson. Half of the respondents among the teachers understood something about SSI-based lessons, but $70 \%$ of them did not apply it as they considered it as something new that they are not really familiar with. This is not very satisfying considering that Karisan suggested that SSI-based learning strategies can enhance and measure learners' scientific literacy and ability to collaborate at them same time [24]. 80\% of the participating teachers agreed that rating learners' ability to collaborate is essential as a part of the 21 st century demand, yet they did not train their learners to collaborate. $60 \%$ of the students admitted that they have never had such training. This results in dissatisfying results of the many attempts to measure learners' ability to collaborate conducted by the teachers. All the teachers 
agreed that there is a need for an SSI-based assessment instrument to measure learners' ability to collaborate.

\subsection{Learners' Perceptions on the Use of SSI-based Lessons to Measure their Ability to Collaborate}

There are not many differences between this case and teachers' perceptions on the use of SSI-based assessment instrument for measuring learners' ability to collaborate. Based on Table 3 , it can be inferred that $85 \%$ of the learners still find it difficult to comprehend science lessons. One of the factors influencing this condition is the fact that only $50 \%$ of the respondents among teachers implemented SSI-based lessons, while the rest still relied on lecturing. During the discussion, only $40 \%$ of the teachers relate the learning materials to the environment and $50 \%$ of them only bring up science facts in certain topics like pollution and climate change. The teachers did not effectively measure learners' ability to collaborate as they judged it based on only three out of five indicators. All of them did not rate learners' ability in time management and contribution in solving problems. Very few of them (21\%) rate learners' performance during the discussion. The same condition can be found in determining students' turn $(61 \%)$ and judging learners' problem-solving skills in the ongoing discussion (39\%). This indicates the need for a better way to measure learners' ability to collaborate as teachers have poor ability in developing an assessment instrument for this.

\section{Conclusion}

This research shows that most teachers (70\%) have not used SSI-based instruments. Most of them (75\%) even have not measured their learners' ability to collaborate. Both students and teachers (100\%) agreed that they need an SSI-based assessment instrument to measure learners' ability to collaborate.

Acknowledgments. The writer would like to thank her co-writers and all parties who where involved in this research. There are no conflicts of interest underlying this study.

\section{References}

[1] Trilling, B \& Fadel, C. 21 st Century Skills: Learning for Life in Our Times. Jossey Bass Wiley: USA. 2009.

[2] Merta, D.K., Undang R., Abdurrahman., dan Agus S. The Development of Higher Orde Thinking Skill (Hots) Instrument Assessment in Physics Study. IOSR Journal of Research \& Method in Education (IOSR-JRME). 2017. Vol7 No 1, pp. 26-32.

[3] Reed, Z.A. Collaborative Learning in the Classroom. Paper submitted as Partial Fulfillment of Master Teacher Program. West Point, NY: United States Military Academy. 2014.

[4] Sadler, T. D., Zeidler, D. L. 2011. The Morality of Socioscientific Issues: Construal and Resolution of Genetic Engineering Dilemmas. Science Education. Vol 88, pp. 4-27.

[5] Greenstein, L. Assessing 21st Century Skills: A Guide to Evaluating Mastery and Learning. Corwin A Sage Company: California. 2012.

[6] Riah, G., Evi, S. dan Suwondo. Integrasi Literasi Sains dan Hots dalam Pembelajaran IPA sebagai Upaya Peningkatan Hasil Belajar Siswa Kelas VII SMP Future Islamic School Pekanbaru. Jurnal Online Mahasiswa (JOM). 2018. Vol 5 No 2, pp. 1-11.

[7] Apriono, D. Implementasi Collaborative Learning dalam Meningkatkan Pemikiran Kritis pada peserta didik. Jurnal Prospektus UNIROW. 2009. Vol 7 No 1, p. 1320. 
[8] Hermawan, P. S., Endi S., dan Achmad S. Desain Rubrik Kemampuan Berkolaborasi SMP dalam Materi Pemantulan Cahaya. Jurnal Penelitian dan Pengembangan Pendidikan Fisika. 2017. Vol 3 No 2, p. 167.

[9] Poerwanti, E. 2001. Asesmen Pembelajaran SD (Konsep Dasar Asesmen pukul 20:10) http://storage.kopertis6.or.id/kelembagaan/Applied\%20App-

[10] Hazrul, I. 2016. Overview of the PISA 2015. [online] https://www.ubaya.ac.id 2014/content/articles_detail/230/Overview-of-the-PISA-2015-result-that-have-just-beedReleased.html retrieved on December 20th 2019.

[11] Redhana, I.W. Mengembangkan Keterampilan Abad Ke-21 dalam Pembelajaran Kimia. Jurnal Inovasi Pendidikan Kimia. 2019. Vol 13 No 1, pp. 2239-2253.

[12] Khishfe, R. Nature of Science and Decision-Making. International Journal of Science Education. 2012. Vol 34 No 1, hal 67-100.

[13] Wulan, A. R. Pengembangan Kreativitas pada Pemebelajaran Sains melalui Asesmen Autentik. Prosiding Seminar Nasional Pendidikan MIPA. 2015. pp. 13-30.

[14] Mulyana, E. H., Ghullam, H., dan Fitri, N. F. Pengembangan Penilaian Sikap dengan Menggunakan Analisis Video Pelaksanaan Pembelajaran Berbasis Konteks. Prosiding Seminar Nasional Pendidikan Sains (SNPS). Universitas Sebelas Maret. 2016. pp. 367-374.

[15] Stiggins, R. J. Student Centered Classroom Assessment. Merril: New York. 1994.

[16] Sunarti and Rahmawati, S. Penilaian dalam Kurikulum 2013. Andi: Yogyakarta. 2014.

[17] Tim Penyusun. Permendikbud Nomor 16 Tahun 2013 tentang Standar Penilaian. Jakarta: Kemdikbud. 2013.

[18] Nuangchalerm, P. Engaging students to perceive nature of science through socioscientific issuesbased instruction. European Journal of Social Sciences. 2010. Vol 13 No1, pp. 34-37.

[19] Sudjana, N. Metode Statistika. Transito: Bandung. 2005.

[20] Arikunto, S. Dasar-Dasar Evaluasi Pendidikan. Bumi Aksara: Jakarta. 2008.

[21] Rakhmawan, A., Setiabudi, A., \& Mudzakir, A. Perancangan Pembelajaran Literasi Sains Berbasis Inkuiri pada Kegiatan Laboratorium. Jurnal Penelitian dan Pembelajaran IPA. 2015. Vol 1 No 1, pp. 143-152.

[22] Alvermann, D. E \& Hayes, D. A. Classroom Discussion of Content Area Reading Assigments: An Intervention Study. Reading Research Quarterly. 1989. Vol 24 No 3, p. 305.

[23] Dawson, V \& Venvillr, G. J. High School Student's Informal Reasoning and Argumentation about Biotechnology: An Indicator of Science Literacy. International Journal of Science Education. 2009. Vol 31 No 11, pp. 1421-1445.

[24] Karisan, D, \& Zeidler, D.L. Contectualization of Nature of Science Withihn the Socioscientific Issue Framework: A Review of Research. International Journal of Education in Mathematics, Science and Technology. 2017. Vol 5 No 2, pp. 139-152.

[25] Muiz, A., Wilujeng, I., Jumadi \& Senam. Implementasi Model Susan Loucks-Horsley Terhadap Communication and Collaboration Peserta Didik SMP. Unnes Science Education Journal. 2016. Hal 1079-1084. 